\title{
EXAMINING KEY DRIVERS FOR ONLINE IMPULSE BUYING IN MALAYSIAN'S PUBLIC UNIVERSITIES STUDENTS
}

\author{
Lu Man Hong ${ }^{*}$, Muhammad Azim Abu Hassan Sha'ari², Chee Jia Jin, Chen Jie Hunn', \\ Bong Shwu Ching ${ }^{5}$ \\ 1,3,45 Faculty of Business and Entrepreneurship, Universiti Malaysia Kelantan, Malaysia \\ ${ }^{2}$ Department of Muamalat, Sultan Ismail Petra International Islamic College, Kota Bharu, Kelantan \\ Email: ${ }^{1}$ vicklumanhong@gmail.com; ${ }^{2}$ azimabuhassan@gmail.com; \\ 3ijiajin.a16a1263@siswa.umk.edu.my; ${ }^{4}$ jiehunn.a16a1265@siswa.umk.edu.my; \\ ${ }^{5}$ shwuching.a16a1260@siswa.umk.edu.my \\ *Corresponding author
}

\begin{abstract}
With the current growth of the internet, there are signs of e-commerce in Malaysia growing and booming. E-commerce entrepreneurs devised a new strategy for increasing sales by increasing the rate of online impulse purchases among visitors to online shopping platforms. Oppositely, online impulse buying caused the rate of bankruptcy among Malaysian especially youth been increased. This research aimed to look into the motivation factors for online impulse buying among Malaysian public universities students. The study addressed empirical results from a 303-respondent online survey conducted with SPSS version 22.0 and Smart-PLS version 3.0. The research paradigm focused on the Theory of Planned Behavior (TPB) model, which included online impulse buying as a dependent variable and three independent variables (Flow Experience, Perceived Usefulness, and Trust). Non-probability methods, judgement sampling and convenience sampling were used to select respondents in this research. The respondents in this study were students who ranged in age from 19 to over 30 years old at public universities in Malaysia. In addition, this research paved the way for future studies by identifying relevant online purchase platform providers and product categories to conduct a new study.
\end{abstract}

Keywords: Flow experience, online impulse buying, perceived usefulness, trust.

\section{Introduction}

In Malaysia, the development of the Internet has accelerated on an annual basis. According to a study released by the Malaysian Communication and Multimedia Commission (MCMC) in 2020, 64.2 percent of Malaysian internet users used the internet for online shopping compared to 53.3 percent in 2018. These data provide insight into the growth of e-commerce and online shopping platform providers in Malaysia, specifically on online purchasing behavior, indicating that Malaysians support the benefits of e-commerce. According to a recent survey conducted by the Asian Institute of Finance (AIF), Malaysians in their early 20s and 30s tend to overspend when making impulse purchases online, which is one of the main reasons why they are in debt at such a young age (Malay Mail, 2015). Thus, this study intent to identify the factors that motivate online consumers to buy impulsively in Malaysia.

Research on online impulse buying by Xiang, Zheng, Lee, and Zhao (2016) confirmed the effect of perceived usefulness and perceived enjoyment on the desire to purchase impulsively. Furthermore, since trust has been shown to have a major impact on online purchasing intent, Malaysian online sellers, as well as the government, should take concrete steps to create strong customer trust to accelerate the growth of the country's online shopping market (Muda, Mohd, \& Hassan, 2016; Hong, Che Nawi, Hamsani, \& Wan Zulkifli, 2020). Furthermore, flow experience, a positive emotional experience of internal enjoyment, arouses positive emotions in consumers, encourages purchasing behaviors, and has a positive impact on customer satisfaction and repurchase intention. As a result, the association between online impulse buying behavior and flow experience, perceived usefulness, and confidence was investigated in this research. As a result, the goals of this study are to look into the factors that drive online impulse buying among Malaysian students at public universities.

\section{Online Impulse Buying Behavior}

According to Khan, Hui, Chen, and Hoe (2016), impulse buying is described as an unplanned transaction in which consumers purchase without intending to do so. When a customer has a sudden, strong, and persistent desire to purchase something right away, this is referred to as impulse buying. According to Lindsey- 
Mullikin and Borin (2017), merchandise purchases and online shopping are increasing over time, competition among different online shopping platform providers is increasing, and online impulse buying is one of the factors contributing to the online shopping platform provider's revenue. This means that online shopping platform providers can ensure that they can handle customer behavior to boost revenue by increasing the likelihood of impulse purchases, which improves the customer experience when shopping on their platforms. In contradict, online impulse buying being bad for consumers since it defined as wastage (Malay Mail, 2015).

\section{Flow Experience}

According to $\mathrm{Wu}$, Chen, and Chiu's (2016) research, flow is a psychological state that refers to the holistic feelings that people have when they behave with a high level of involvement. According to Tommy, Mimoi, and Sian (2017) and Huang (2016), the flow experience is a state of optimal psychological experience in which an individual becomes fully focused on his or her behavior and experiences several positive experiential characteristics such as great pleasure and loss of self-awareness. In impulse buying, a person will focus their attention on a very narrow range, filtering out irrelevant thoughts and expectations and losing their sense of self-awareness. Hence, the hypothesis stated as below:

$H_{1}$ : Flow experience related to online impulse buying.

\section{Perceived Usefulness}

According to a study by Akram et al. (2018), online impulse buying is motivated by several factors like hedonic motives, utilitarian motivations, social shopping, adventure shopping, concept shopping, perceived utility, perceived pleasure, visual appeal knowledge fit-to-task, and the desire to buy impulsively. The perceived utility of a website's product knowledge quest is thought to be a significant precursor to consumers' online purchasing actions. As a result, hedonic information systems are associated with the home, while perceived utility is associated with the workplace. Thus, the hypothesis stated as below:

$\mathrm{H}_{2}$ : Perceived usefulness related to online impulse buying.

\section{Trust}

Jin, Line, and Merkebu (2016), who claim that trust helps customers feel at ease, which improves the efficiency and effectiveness of relational exchanges. Normally, business transactions are conducted without a contract or other safeguards against opportunistic activity in the context of social exchange (Wu et al., 2016). As a result, e-commerce customers' faith in a website's goodness means that they believe the website will behave in the best interests of its customers, not just it is own when making a transaction (Wang, Wang, $\& \mathrm{Liu}, 2016$ ). As a result, customers would value a website's willingness to provide high-quality service, which is an indication that a website will demonstrate honesty and trustworthiness (Kim, \& Peterson, 2017). Hence, the hypothesis formed as below:

$H_{3}$ : Trust related to online impulse buying.

\section{Research Framework}

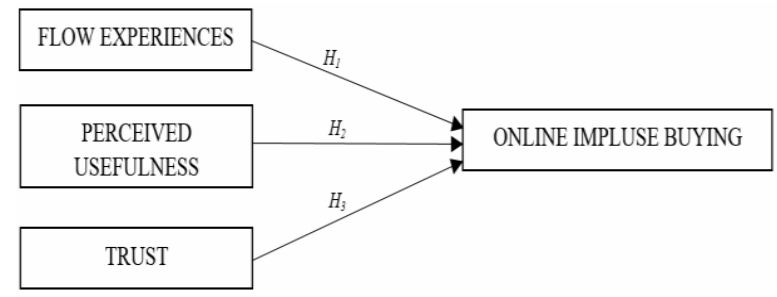

Figure 1. Research framework

The figure below showed the relationship between online impulse buying and flow experience, perceived usefulness, and trust among Malaysian public university students was investigated using a research framework.

\section{Research Method}

The numeric calculation, also known as quantitative analysis, was used in this study. The respondents in this study were public university students aged 20 to over 30 who had purchased items online at least once on an online shopping platform. The sample size for this research was calculated by rules of thumb, which stated that sample sizes should be greater than 30 and less than 500. Since the responses were obtained using online questionnaires generated using Google form with the English language, the respondents were chosen using the non-probability sampling technique, judgement, and convenience sampling. To obtain real accurate responses from respondents, all items were built clearly and understandably. In addition, the questionnaire used a 5-point Likert scale ranging from 1 (strongly disagree) to 5 (strongly agree). The questionnaire was divided into three sections: (a) demographic profile of respondents, (b) target respondents' perceptions of online impulse buying by customers, and (c) target 
respondents' perceptions of flow experience, perceived usefulness, and confidence with online impulse buying.

All of the data was analysed using the Statistical Programmers for Social Science (SPSS) version 22.0 software and Smart Partial Least Square (SMART PLS) version 3.0. A pilot study was the first evaluation that the researcher conducted. As a result, 30 responses were collected from the respondents to conduct the pilot study. The outcome of the reliability test is calculated by Cronbach's Alpha value, which must be greater than 0.70, according to Hair, Sarstedt, Ringle, and Mena (2012).

The second test performed was a frequency analysis to summarise the information gathered from the questionnaires. Simply put, this analysed and summarized 303 respondents' demographic profiles into a table format with frequency and percentages. According to Hair et al. (2012), descriptive analysis is the use of statistics to describe variables or generalise knowledge from a sample.

Finally, the SmartPLS Analysis was used to look at the relationships between the variables and assess the relationship's power. The relationship between online impulse buying behavior and flow experience, perceived usefulness, and trust was investigated in this study.

\section{Result and Discussion}

\section{Reliability Analysis}

The reliability test will be used to decide whether the respondents understood all of the embedded items in this study, and the test will be calculated using Cronbach's Alpha values (Hair et al., 2012). The results of the reliability analysis of all variables in this study are shown in Table 1.

Cronbach's Alpha values in this analysis range from 0.72 to 0.84 , as shown in Table 1 . Since the value of Cronbach's Alpha is greater than 0.70, as recommended by Hair et al. (2012), all variables in this study are accurate.

Table 1

Reliability Analysis

\begin{tabular}{lcc}
\hline \multicolumn{1}{c}{ Factors } & $\begin{array}{c}\text { Number of } \\
\text { items }\end{array}$ & Cronbach's Alpha \\
\hline Online Impulse & 8 & 0.84 \\
Buying & & \\
Flow Experience & 8 & 0.74 \\
Perceived & 8 & 0.77 \\
Usefulness & 6 & 0.72 \\
Trust & 6 & \\
\hline
\end{tabular}

\section{Frequency Analysis}

Table 2

Summary of Demographic Profile

\begin{tabular}{|c|c|c|}
\hline \multirow{2}{*}{ Identity } & \multicolumn{2}{|c|}{ Frequency Percentage } \\
\hline & & \\
\hline$\overline{\text { Student }}$ & 303 & 100 \\
\hline Non-Student & 0 & 0 \\
\hline \multicolumn{3}{|l|}{ Public University } \\
\hline $\begin{array}{l}\text { Universiti Islam Antarabangsa Malaysia } \\
\text { (UIAM) }\end{array}$ & 3 & 1.00 \\
\hline Universiti Kebangsaan Malaysia (UKM) & 7 & 2.30 \\
\hline Universiti Malaysia Kelantan (UMK) & 101 & 33.30 \\
\hline Universiti Malaya (UM) & 17 & 5.60 \\
\hline Universiti Malaysia Pahang (UMP) & 26 & 8.60 \\
\hline Universiti Malaysia Sarawak (UNIMAS) & 21 & 6.90 \\
\hline Universiti Malaysia Perlis (UniMAP) & 23 & 7.60 \\
\hline Universiti Malaysia Sabah (UMS) & 22 & 7.30 \\
\hline $\begin{array}{l}\text { Universiti Pertahanan Nasional Malaysia } \\
\text { (UPNM) }\end{array}$ & 4 & 1.30 \\
\hline Universiti Pendidikan Sultan Idris (UPSI) & 6 & 2.00 \\
\hline Universiti Putra Malaysia (UPM) & 18 & 5.90 \\
\hline Universiti Sains Islam Malaysia (USIM) & 3 & 1.00 \\
\hline Universiti Sains Malaysia (USM) & 12 & 4.00 \\
\hline Universiti Teknologi Malaysia (UTM) & 17 & 5.60 \\
\hline $\begin{array}{l}\text { Universiti Tun Hussein Onn Malaysia } \\
\text { (UTHM) }\end{array}$ & 7 & 2.30 \\
\hline $\begin{array}{l}\text { Universiti Teknikal Malaysia Melaka } \\
\text { (UTeM) }\end{array}$ & 8 & 2.60 \\
\hline Universiti Teknologi MARA(UiTM) & 5 & 1.70 \\
\hline Universiti Utara Malaysia (UUM) & 2 & 0.70 \\
\hline Other Universiti & 1 & 0.30 \\
\hline \multicolumn{3}{|l|}{ Gender } \\
\hline$\overline{\text { Male }}$ & 105 & 34.70 \\
\hline Female & 198 & 65.30 \\
\hline \multicolumn{3}{|l|}{ Age } \\
\hline 19-24 Years Old & 225 & 74.30 \\
\hline 25-30 Years Old & 72 & 23.80 \\
\hline Above 30 Years Old & 6 & 2.00 \\
\hline \multicolumn{3}{|c|}{ Years of Experience with Online Shopping Platform } \\
\hline Less than 1 Year & 88 & 29.00 \\
\hline $1-3$ Years & 142 & 46.90 \\
\hline 4-6 Years & 67 & 22.10 \\
\hline 7-9 Years & 5 & 1.70 \\
\hline More than 9 Years & 1 & 0.30 \\
\hline Less than 1 Hour & 91 & 30.00 \\
\hline 1-4 Hours & 128 & 42.20 \\
\hline 5-8 Hours & 57 & 18.80 \\
\hline 9-12 Hours & 22 & 7.30 \\
\hline 13-18 Hours & 4 & 1.30 \\
\hline More than 18 Hours & 1 & 0.30 \\
\hline \multicolumn{3}{|l|}{ Most Used Electronic Device } \\
\hline$\overline{\text { Smartphone }}$ & 207 & 68.30 \\
\hline Laptop & 55 & 18.20 \\
\hline Desktop & 18 & 5.90 \\
\hline Tablet & 23 & 7.60 \\
\hline \multicolumn{3}{|l|}{ Most Used Shopping Platform } \\
\hline Lazada & 49 & 16.20 \\
\hline Zalora & 22 & 7.30 \\
\hline Mudah.my & 33 & 10.90 \\
\hline Shopee & 130 & 42.90 \\
\hline 11Street & 15 & 5.00 \\
\hline Other & 54 & 17.80 \\
\hline Total & 303 & 100 \\
\hline
\end{tabular}


Table 2 indicates that University Malaysia Kelantan students are the most numerous in this report. Females make up 198 of the 303 respondents, with 225 of them being between the ages of 19 and 24. Aside from that, 142 of the respondents had 1 to 3 years of experience with an online shopping site, followed by 82 respondents with less than 1 year of experience. The majority of respondents spend 1 to 4 hours a day on the internet. The majority of respondents still use their smartphones to access the internet. According to the respondents in this survey, Shopee is the most popular shopping site.

\section{Measurement Model Analysis}

Table 3

Measurement Model Result

\begin{tabular}{ccccc}
\hline Construct & Item & Loading & CR & AVE \\
\hline Online Impulse Buying & OIB1 & 0.82 & 0.90 & 0.54 \\
& OIB2 & 0.41 & & \\
& OIB3 & 0.86 & & \\
& OIB4 & 0.62 & & \\
& OIB5 & 0.71 & & \\
& OIB6 & 0.68 & & \\
& OIB7 & 0.78 & & \\
& OIB8 & 0.87 & & \\
Flow Experience & FE1 & 0.78 & 0.81 & 0.59 \\
& FE2 & 0.80 & & \\
Perceived Usefulness & FE6 & 0.72 & & \\
& PU1 & 0.84 & 0.79 & 0.56 \\
& PU4 & 0.80 & & \\
& PU8 & 0.59 & & \\
Trust & TR1 & 0.82 & 0.77 & 0.53 \\
& TR3 & 0.61 & & \\
& TR5 & 0.74 & & \\
\hline
\end{tabular}

The variables and indicators in this analysis are accurate and reliable, as shown in Table 3. According to Hair et al. (2012), loading values must be greater than 0.71 , and the average variance extracted (AVE) value must be greater than 0.50 . The value of composite durability (CR) must be greater than 0.80 (Henseler, Ringle, \& Sinkovics, 2009). Finally, in the following section, the four evaluations of the measurement model study will be addressed.

\section{Internal Consistency}

The composite reliability and loading range values for each variable in this analysis are shown in Table 4.

The items in this study are reliable because the composite reliability of each build is greater than 0.80 , and they met the internal quality testing requirements proposed by Henseler and Chin (2010) which the CR value must be greater than 0.60 .
Table 4

Composite Reliability and Loading Range Analysis

\begin{tabular}{cccc}
\hline Construct & $\begin{array}{c}\text { Composite } \\
\text { Reliability }\end{array}$ & $\begin{array}{c}\text { Loading } \\
\text { Range }\end{array}$ & $\begin{array}{c}\text { Number of } \\
\text { Items Deleted }\end{array}$ \\
\hline Online Impulse & 0.90 & $0.41-0.87$ & - \\
$\quad$ Buying & & & \\
Flow Experience & 0.81 & $0.72-0.80$ & 5 \\
$\quad \begin{array}{c}\text { Perceived } \\
\text { Usefulness }\end{array}$ & 0.79 & $0.59-0.84$ & 5 \\
$\quad$ Trust & 0.77 & $0.61-0.82$ & 3 \\
\hline
\end{tabular}

\section{Factor Loading}

Table 5

Factor Loadings Analysis

\begin{tabular}{|c|c|c|c|c|}
\hline \multirow[t]{2}{*}{ Construct } & \multirow[t]{2}{*}{ Indicators } & \multicolumn{2}{|c|}{ Loadings } & \multirow[t]{2}{*}{ Comments } \\
\hline & & Before & After & \\
\hline \multirow{8}{*}{$\begin{array}{l}\text { Online Impulse } \\
\text { Buying }\end{array}$} & OIB1 & 0.81 & 0.82 & - \\
\hline & OIB2 & 0.43 & 0.41 & - \\
\hline & OIB3 & 0.86 & 0.86 & - \\
\hline & OIB4 & 0.62 & 0.62 & - \\
\hline & OIB5 & 0.70 & 0.71 & - \\
\hline & OIB6 & 0.69 & 0.68 & - \\
\hline & OIB7 & 0.78 & 0.78 & - \\
\hline & OIB8 & 0.86 & 0.87 & - \\
\hline \multirow[t]{8}{*}{ Flow Experience } & FE1 & 0.73 & 0.78 & - \\
\hline & FE2 & 0.72 & 0.80 & - \\
\hline & FE3 & 0.38 & - & Deleted \\
\hline & FE4 & 0.56 & - & Deleted \\
\hline & FE5 & 0.48 & - & Deleted \\
\hline & FE6 & 0.55 & 0.72 & - \\
\hline & FE7 & 0.29 & - & Deleted \\
\hline & FE8 & 0.31 & - & Deleted \\
\hline \multirow{8}{*}{$\begin{array}{l}\text { Perceived } \\
\text { Usefulness }\end{array}$} & PU1 & 0.71 & 0.84 & - \\
\hline & PU2 & 0.44 & - & Deleted \\
\hline & PU3 & 0.40 & - & Deleted \\
\hline & PU4 & 0.54 & 0.80 & Deleted \\
\hline & PU5 & 0.44 & - & Deleted \\
\hline & PU6 & 0.28 & - & Deleted \\
\hline & PU7 & 0.47 & - & Deleted \\
\hline & PU8 & 0.53 & 0.59 & - \\
\hline \multirow[t]{6}{*}{ Trust } & TR1 & 0.73 & 0.82 & - \\
\hline & TR2 & 0.42 & - & Deleted \\
\hline & TR3 & 0.59 & 0.61 & - \\
\hline & TR4 & 0.47 & - & Deleted \\
\hline & TR5 & 0.68 & 0.74 & - \\
\hline & TR6 & 0.57 & - & - \\
\hline
\end{tabular}

The factor loadings for each component in the variables are shown in Table 5. According to Hair et al., indicators from all variables and online impulse purchasing have a loading value of more than 0.71 . (2012). Due to loading values of less than 0.71, researchers removed 13 indicators (FE3, FE4, FE5, FE7, FE8, PU2, PU3, PU5, PU6, PU7, TR2, TR4, and TR6). However, the researchers agreed to keep five indicators (OIB2, OIB4, OIB6, PU8, and TR3) because it is fair to keep indicators if the loading values are less than 0.71 to 0.4 when the $C R$ value and average variance extracted (AVE) are met. 


\section{Convergent Validity}

Convergent validity is used to evaluate and classify all of the elements that can be used to assess the construct under the terms of the agreement. The convergent validity outcome of this analysis is shown in Table 6 , and all of the metrics are appropriate to be used as a calculation of the construct in this study since the AVE is greater than 0.50 .

Table 6

\section{Convergent Validity Result}

\begin{tabular}{cccc}
\hline Construct & Item & Loading & AVE \\
\hline Online Impulse Buying & OIB1 & 0.82 & 0.54 \\
& OIB2 & 0.41 & \\
& OIB3 & 0.86 & \\
& OIB4 & 0.62 & \\
& OIB5 & 0.71 & \\
OIB6 & 0.68 & \\
& OIB7 & 0.78 & \\
Flow Experience & OIB8 & 0.87 & \\
& FE1 & 0.78 & 0.59 \\
Perceived Usefulness & FE2 & 0.80 & \\
& FE6 & 0.72 & \\
Trust & PU1 & 0.84 & 0.56 \\
& PU8 & 0.80 & \\
& TR1 & 0.59 & \\
& TR3 & 0.82 & 0.53 \\
& TR5 & 0.61 & \\
\hline
\end{tabular}

\section{Discriminant Validity}

Multicollinearity issues among the constructs in this study are identified using discriminant validity. Kline (2011) suggests using strict heterotrait-monotrait (HTMT.85) parameters as a calculation. Table 7 shows the discriminant validity results, which suggest that there are fewer multicollinearity issues among the constructs in this study since the value is less than 0.85 . While Table 8 show Fornell and lacker criteria and it showed fewer multicollinearity issues if each item loading value must be highest on it is associated construct.

Table 7

Discriminant Validity of Constructs (Stringent Criterion)

\begin{tabular}{ccccc}
\hline & FE & OIB & PU & TR \\
\hline FE & & & & \\
OIB & 0.82 & & & \\
PU & 0.72 & 0.54 & & \\
TR & 0.72 & 0.86 & 0.81 & \\
\hline
\end{tabular}

Note: $\mathrm{FE}=$ Flow Experience; OIB= Online Impulse Buying; $\mathrm{PU}=$ Perceived Usefulness; $\mathrm{TR}=$ Trust

Table 8

Discriminant validity of constructs (Fornell and lacker criteria)

\begin{tabular}{ccccc}
\hline & FE & OIB & PU & TR \\
\hline FE & $\mathbf{0 . 7 7}$ & & & \\
OIB & 0.65 & $\mathbf{0 . 7 8}$ & & \\
PU & 0.49 & 0.43 & $\mathbf{0 . 8 5}$ & \\
TR & 0.42 & 0.57 & 0.34 & $\mathbf{0 . 7 1}$ \\
\hline
\end{tabular}

Note: $\mathrm{FE}=$ Flow Experience; OIB= Online Impulse Buying; $\mathrm{PU}=$ Perceived Usefulness; TR $=$ Trust

\section{Path Coefficient}

Table 9

The Path Coefficient Result

\begin{tabular}{ccccc}
\hline Hypothesis & $\begin{array}{c}\text { Direct } \\
\text { Effect }(\boldsymbol{\beta})\end{array}$ & t-statistic & $\boldsymbol{p}$-value & Significant \\
\hline$H_{1}$ & 0.46 & 8.36 & 0.00 & Significant \\
$H_{2}$ & 0.03 & 0.55 & 0.58 & Non-Significant \\
$H_{3}$ & 0.37 & 5.81 & 0.00 & Significant \\
\hline
\end{tabular}

The hypothesis between flow experience and trust towards online impulse buying is important, according to Table 9, since the $t$-statistic and $p$-value values for hypothesis $1(t$-value $=8.36 ; p$-value $=0.00)$ and hypothesis 3 ( $t$-value $=5.81$.; $p$-value $=0.00)$ are greater than 1.96 and less than 0.05 , respectively. Meanwhile, hypothesis 2 ( $t$-value $=0.55 ; p$-value $=$ $0.58)$ is non-significant since the $t$-statistic and $p$-value values for hypothesis $2(t$-value $=0.55 ; p$-value $=0.58)$ are less than 1.96 and more than 0.05 , respectively.

\section{Discussion}

The study's main goal is to look at the factors that influence online impulse purchases. Flow experience was linked to online impulse purchases in a positive and meaningful way. The flow experience is characterised as a state of optimal psychological experience when a person becomes entirely focused on his or her behavior and feels several positive experiential characteristics such as great pleasure and loss of self-awareness, according to a study by Tommy et al. (2017). Furthermore, Wu et al. (2016) support the findings, stating that the flow experience is a mediator that influences impulse buying from the perspective of web skills and challenges. The experience of relevant systems such as search engines, recommendation systems, transaction protection systems, and other factors that allow the discovery of desired information can influence the perception of control.

Customers' perceptions of utility and attitudes toward online shopping affect their decision to purchase online (Tandon, Kiran, \& Sah, 2016). This supports the findings of Xiang et al. (2016), who found that knowledge fit-to-task, visual appeal, perceived utility, and perceived pleasure are all significant drivers of the desire to buy impulsively. However, the results of this study revealed that perceived utility is unimportant and has a negative impact on online impulse buying among the study's participants. According to Chen, Yeh, and Lo (2017), there is no important relationship between perceived usefulness and online impulse buying. Besides, a study by $\mathrm{Liu}, \mathrm{Li}$, and $\mathrm{Hu}$ (2013) justified there is no substantial relationship between ease of use and the desire to purchase impulsively. 
Online impulse buying was positively and substantially linked to trust. This finding is supported by Yu, Mai, Tsai, and Dai's (2018) research, which found that trust is crucial in all aspects of social life because it can foster individual friendships, build favourable bargaining and negotiating conditions, and lower individual transaction costs. Furthermore, Jin et al. (2016) endorsed the findings, stating that confidence helps consumers feel at ease, which enhances the efficiency and effectiveness of relational exchanges. Business transactions are typically conducted without the use of a contract or other safeguards against opportunistic activity in the context of social exchange.

As a result, this study aimed to identify the main factors that influence online impulse buying. This is due to the researcher's belief that this study will provide valuable insights into the current and future retail industry in Malaysia, as online retailing is expected to overtake conventional brick and mortar in line with global trends. According to the latest global trend, online retailing would supplant conventional brick and mortar stores. By adding more demographic details about the customers and conducting a new study using a particular online shopping platform, this study offered potential research opportunities. Furthermore, online shopping platform providers have established flow experience and confidence as factors that influence online impulse purchases. Furthermore, through conducting this research, customers learned about the challenges that could be encountered in online impulse buying and how to solve them.

\section{Conclusions and Implications}

The goal of this study was to see how utilitarian and hedonic value online feedback influenced browsing, how browsing influenced impulsive buying urges, how impulsive buying urges influenced online impulse buying actions, how browsing mediated impulsiveness, and how impulsiveness mediated browsing. Surprisingly, the target respondents say that hedonic value online reviews contribute to impulse purchases when they visit the website. Furthermore, their online impulse buying acts are influenced by their website surfing. As a result, this can provide convincing proof that the vast majority of Malaysian online customers visit websites for entertainment purposes.

Even though this research provided useful information about the Malaysian e-commerce industry. There are a couple of shortcomings in this study. To begin with, there are only 100 participants in this study who were unable to provide a detailed explanation of how online reviews influence online impulse buying behavior. Furthermore, the study's participants are regular online shoppers who have made at least one purchase on Lazada Malaysia and Shopee Malaysia.
As a result, several research proposals have been made for the future. To begin with, future research should increase the number of responses to obtain more accurate results to better understand the effect of online feedback on online impulse buying behavior. After that, future research might focus on or a specific product sales channel, such as Hermo, a beauty and healthcare website. Finally, different target respondent classes, such as females and males, as well as students, may have varying viewpoints on online reviews and online impulse buying behavior.

\section{Limitation and Future Recommendations}

As researchers interpreted the study's findings, some shortcomings were discovered. To begin, researchers gathered information from Malaysian public university students aged 19 to 30 who had done at least one online shopping transaction. Although the study's target respondents engage in online shopping, this does not accurately represent the entire population. This is because target respondents in this age group were not ideal. After all, they were an internet-savvy group. To achieve a better outcome in future studies, the researchers proposed expanding the variety of possible respondents based on age groups. To achieve a better outcome in future studies, the researchers proposed expanding the variety of possible respondents based on age groups. This adds to the body of research demonstrating how consumers behave when it comes to online impulse purchases.

This study looked at how flow knowledge, perceived utility, and confidence in various online shopping platforms influenced online impulse buying. Other potential variables such as website attributes and online review can be considered as determinants factors for future studies. Furthermore, this was not a survey of individual websites, which would have resulted in different responses from respondents. In order to achieve a stronger and more specific outcome in future studies, the researchers recommended focusing on one online shopping platform such as Lazada, Mudah.com, Taobao and more rather than several websites. This is due to the various expectations that customers have when they have an online impulse buying experience based on a particular online shopping site.

\section{References}

Akram, U., Hui, P., Khan, M. K., Tanveer, Y., Mehmood, K., \& Ahmad, W. (2018). How website quality affects online impulse buying: Moderating effects of sales promotion and credit card use. Asia Pacific Journal of Marketing and Logistics, 30 (1), 235-256. https://doi.org/10. 1108/APJML-04-2017-0073 
Chen, T.-Y., Yeh, T.-L., \& Lo, W.-C. (2017). Impacts on online impulse purchase through perceived cognition. Journal of International Consumer Marketing, 29(5), 319-330. https://doi.org/10. 1080/08961530.2017.1367208

Hair, J. F., Sarstedt, M., Ringle, C. M., \& Mena, J. A. (2012). An assessment of the use of partial least squares structural equation modeling in marketing research. Journal of the Academy of Marketing Science, 40, 414-433. https://doi.org/10. 1007/s11747-011-0261-6

Henseler, J., \& Chin, W. W. (2010). A comparison of approaches for the analysis of interaction effects between latent variables using partial least squares path modeling. Structural Equation Modeling: A Multidiciplinary Journal, 17(1), 82-109. https://doi.org/10.1080/1 0705510903439003

Henseler, J., Ringle, C. M., \& Sinkovics, R. R. (2009). The use of partial least squares path modeling in international marketing. In Sinkovics, R. R., \& Ghauri, P. N. (Eds.) New challenges to international marketing (Advances in International Marketing, 20), Emerald Group Publishing Limited, Bingley, pp. 277-319. https://doi.org/ 10.1108/S1474-7979(2009)0000020014

Hong, L. M., Che Nawi, N., Hamsani, N. H., \& Wan Zulkifli, W. F. (2020). Online store image effect on perceievd risks towards online purchasing behavior. International Journal Business Information Systems, 35(1), 27-44. http://dx.doi.org/ 10.1504/IJBIS.2020.109530

Huang, L. T. (2016). Flow and social capital theory in online impulse buying. Journal of Business Research, 69(6), 2277-2283. https://doi.org/10.1016/ j.jbusres.2015.12.042

Jin, N., Line, N. D., \& Merkebu, J. (2016). The impact of brand prestige on trust, perceived risk, satisfaction, and loyalty in upscale restaurants. Journal of Hospitality Marketing \& Management, 25(5), 523-546. https://doi.org/10.1080/19368 623.2015.1063469

Khan, N., Hui, L. H., Chen, T. B., \& Hoe, H. Y. (2016). Impulse buying behavior of Generation $\mathrm{Y}$ in fashion retail. International Journal of Business and Management, 11(1), 144-151. https://doi. org/10.5539/ijbm.v11n1p144

Kim, Y., \& Peterson, R. A. (2017). A Meta-analysis of online trust relationships in ecommerce. Journal of Interactive Marketing, 38, 44-54. http://dx.doi. org/10.1016/j.intmar.20 17.01.001

Kline, R. B. (2011). Convergence of structural equation modeling and multilevel modeling. In $\mathrm{M}$. Williams, \& W. P. Volt (Eds), The SAGE handbook of innovation in social research methods (pp. 562-589). SAGE Publications Ltd. https://www.doi.org/10.4135/97 81446268261
Lindsey-Mullikin, J., \& Borin, N. (2017). Why strategy is key for successful social media sales. Business Horizons, 60(4), 473-482. https://doi. org/10.1016/j.bushor.2017.03.005

Liu, Y., Li, H., \& Hu, F. (2013). Website attributes in urging online impulse purchase: An empirical investigation on consumer perceptions. Decision Support Systems, 55, 829-837. http://dx.doi.org/ 10.1016/j.dss.2013.04. 001

Malay Mail. (2015). Digitally savvy Malaysian youths in debt due to impulse buys, survey shows. Retrieved from https://www.malaymail.com/ news/malaysia/2015/10/15/digitally-savvymalaysian-youths-in-debt-due-to-impu lse-buyssurvey-shows/987527

Muda, M., Mohd, R., \& Hassan, S. (2016). Online purchase behavior of Generation $\mathrm{Y}$ in Malaysia. Procedia Economics and Finance, 37, 292-298. https://doi.org/10.1016/S2212-567 1(16)30127-7

Tandon, U., Kiran, R., \& Sah, A. N. (2016). Customer satisfaction using website functionality, perceived usability and perceived usefulness towards online shopping in India. Information development, 32(5), 1657-1673. https ://doi.org/10.1177\%2F0 266666915621106

Tommy, C. A., Minoi, J. L., \& Sian, C. S. (2017). Game usability heuristics evaluation approach for speech therapy mobile application games. Journal of Telecommunication, Electronic and Computer Engineering (JTEC), 9(3-11), 93-97.

Wang, W. T., Wang, Y. S., \& Liu, E. R. (2016). The stickiness intention of group-buying websites: The integration of the commitment-trust theory and e-commerce success model. Information \& Management, 53, 625-642. http://dx.doi.org/10. 1016/j.im.2016.01.006

Wu, I.-L., Chen, K.-W., \& Chiu, M.-L. (2016). Defining key drivers of online impulse purchasing: A perspective of both impulse shoppers and system users. International Journal of Information Management, 36(3), 284-296. doi:10.1016/ j.ijinfomgt.2015.11.015

Xiang, L., Zheng, X., Lee, M. K., \& Zhao, D. (2016). Exploring consumers' impulse buying behavior on social commerce platform: The role of parasocial interaction. International Journal of Information Management, 36 (3), 333-347. http://dx.doi.org/10.1016/j.ijin fomgt.2015.11.002

Yu, M. C., Mai, Q., Tsai, S. B., \& Dai, Y. (2018). An empirical study on the organizational trust, employee-organization relationship and innovative behavior from the integrated perspective of social exchange and organizational sustainability. Sustainability, 10(864), 1-14. https://doi.org/10. 3390/su10030864 